\title{
THE PAPERS OF \\ THOMAS JEFFERSON
}

RETIREMENT SERIES 



\title{
THE PAPERS OF Thomas Jefferson
}

RETIREMENT SERIES

\section{Volume 15}

1 September 1819 to 31 May 1820

\author{
J. JEFFERSON LOONEY, \\ THE DANIEL P. JORDAN EDITOR
}

JULIE L. LAUTENSCHLAGER AND ROBERT F. HAGGARD, SENIOR ASSOCIATE EDITORS

ELLEN C. HICKMAN, ASSOCIATE EDITOR ANDREA R. GRAY, ASSISTANT EDITOR LISA A. FRANCAVILLA, MANAGING EDITOR PAULA VITERBO AND KERRY DAHM, EDITORIAL ASSISTANTS

SUSAN SPENGLER, TECHNICAL SPECIALIST CATHERINE CLARKE COINER, SENIOR DIGITAL TECHNICIAN

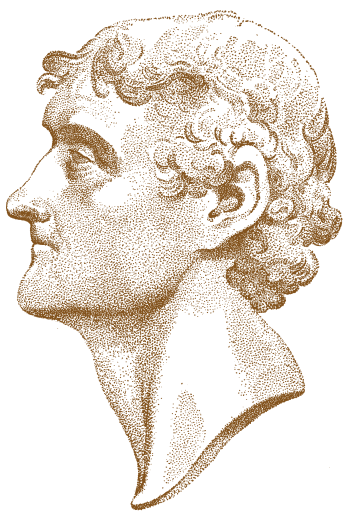

PRINCETON AND OXFORD PRINCETON UNIVERSITY PRESS 
Copyright (C) 2018 by Princeton University Press

Published by Princeton University Press, 41 William Street,

Princeton, New Jersey 08540

In the United Kingdom:

Princeton University Press, 6 Oxford Street, Woodstock, Oxfordshire OX20 ITR

All Rights Reserved

Library of Congress Cataloging-in-Publication Data

Jefferson, Thomas, 1743-1826

The papers of Thomas Jefferson. Retirement series / J. Jefferson Looney, editor . . .

[et al.] p. cm.

Includes bibliographical references and index.

Contents: v. 1. 4 March to 15 November 1809 - [etc.]-

v. 15. 1 September 1819 to 31 May 1820

ISBN 978-0-691-18234-6 (cloth: v. 15: alk. paper)

1. Jefferson, Thomas, 1743-1826-Archives. 2. Jefferson, Thomas, 1743-1826-

Correspondence. 3. Presidents-United States-Archives.

4. Presidents-United States-Correspondence. 5. United States-

Politics and government-1809-1817-Sources. 6. United States-Politics and government-1817-1825-Sources. I. Looney, J. Jefferson.

II. Title. III. Title: Retirement series.

E302.J442 2004b

973.4'6'092-dc22 2004048327

This book has been composed in Monticello

Princeton University Press books are printed on acid-free paper and meet the guidelines for permanence and durability of the Committee on Production

Guidelines for Book Longevity of the

Council on Library Resources

Printed in the United States of America 
DEDICATED TO THE MEMORY OF

\section{ADOLPH S. OCHS}

PUBLISHER OF THE NEW YORK TIMES

$1896-1935$

WHO BY THE EXAMPLE OF A RESPONSIBLE

PRESS ENLARGED AND FORTIFIED

THE JEFFERSONIAN CONCEPT

OF A FREE PRESS 


\section{ADVISORY COMMITTEE}

\author{
LESLIE GREENE BOWMAN \\ CHARLES T. CULLEN \\ JAMES HORN \\ DANIEL P. JORDAN \\ JOHN P. KAMINSKI \\ STANLEY N. KATZ \\ JAMES P. McCLURE \\ JOHN M. MURRIN
}

PETER S. ONUF

ANDREW J. O'SHAUGHNESSY

MARK H. SAUNDERS

DAVID M. SEAMAN

JOHN C. A. STAGG

BRENT TARTER

ALAN TAYLOR

This EDition was made possible by a founding grant from The New York Times Company to Princeton University.

The Retirement Series is sponsored by the Thomas Jefferson Foundation, Inc., of Charlottesville, Virginia. It was created with a six-year founding grant from The Pew Charitable Trusts to the Foundation and to Princeton University, enabling the former to take over responsibility for the volumes associated with Jefferson's retirement. Leading gifts from Richard Gilder, Mrs. Martin S. Davis, Thomas A. Saunders III, Janemarie D. and Donald A. King, Jr., Alice Handy and Peter Stoudt, Harlan Crow, Mr. and Mrs. E. Charles Longley, Jr., and the Abby S. and Howard P. Milstein Foundation have assured the continuation of the Retirement Series. For these essential donations, and for other indispensable aid generously given by librarians, archivists, scholars, and collectors of manuscripts, the Editors record their sincere gratitude.

The position of Editor of the Papers of Thomas Jefferson at Monticello is named in honor of Dr. Daniel P. Jordan, who served as the President of the Thomas Jefferson Foundation and guided Monticello from 1985 to 2008. Dr. Jordan's vision and leadership led to the establishment in 1999 of The Papers of Thomas Jefferson: Retirement Series, part of Monticello's Robert H. Smith International Center for Jefferson Studies, which was also founded during Dr. Jordan's tenure. A challenge grant, generously provided by the Abby S. and Howard P. Milstein Foundation in 2017, made this recognition possible, with matching support from many donors, including John and Renee Grisham, Roger and Susan Hertog, Mrs. Walter H. Helmerich III, Richard Gilder and Lois Chiles, J.F. and Peggy Bryan, Charles T. Cullen, Grady and Lori Durham, Brent and Lindsay Halsey, Janemarie D. and Donald A. King, Jr., and John L. Nau III. 